Protection of Manufactures

Vincent Cable,

Overseas Development Institute, London 


\section{Protection of Manufactures}

\section{CONTENTS}

$\underline{\text { Page }}$

I. Introduction

II. Textiles, Clothing and Footwear

188

III. Engineering Goods

IV. Semi-Manufactures: Chemicals, Metals,

Paper and Board, etc.

V. Other Manufactures

VI. Conclusions

\section{TABLES}

1.1 Export Structure of non-oil Ldcs: Manufactures

1.2 Shares of "Mainly Managed" Goods in OECD and EEC Trade

1.3 Share of Imports in the Apparent Consumption of

Manufactured Goods in Industrial Countries

1970-80: by Industrial Country

1.4 Market Penetration by Ldcs of Industrial Countries' Markets in 1979

1.5 The Importance of Different Categories of Manufactures

for Major Ldcs Suppliers

2.1 Balance of Textile and Clothing Trade, 1963, 1973, 1978-1980

2.2 Import Increments, Developed Country Members of the MFA

2.3 Real Growth Rates of Imports of Clothing and Textiles from Four Groups of Countries into Industrialised Countries of Western Europe and North America: 1963-73, 1973-76 and 1976-79

3.1 Developing Countries' Trade in Engineering Goods

3.2 Engineering Goods Imports (by Sub-product) into 205

Industrial Countries 


\section{Protection of Manufactures}

\section{Introduction}

1. Some developing countries have enjoyed considerable success in the export of manufactured goods and a growing number of others are producing a wider range of these products competitively. However, international agencies - particularly GATT, the World Bank and the IMF - regularly warn of the growing danger which protectionism poses to both the international trading and financial systems. They have also chronicled a recent relapse, after the deterioration in the climate of trade policy in the period 1974-78 had apparent $1 \mathrm{y}$ been stopped by the advances in trade liberalisation agreed in the Tokyo Round of negotiations: "protectionism (defined to encompass pressures for protection as well as policy concessions

to them) continued to gather strength in the past year". 1

2. In making an overall assessment of the extent and significance of trade restrictions for developing country exporters we need to be able to quantify several elements: the volume of trade which is actual1y restrained; the extent to which trade restraint results in divergences between domestic prices in the country restricting trade and international prices; the effects of the measures, then, on demand and supply. Estimation of each of these poses considerable difficulties. For example, exporters are affected indirect1y - by depressed expectations and the encouragement of cartelisation and other uncompetitive behaviour - rather than in any immediately quantifiable way.

\section{Tariff and Non-Tariff Barriers}

3. One of the most serious difficulties in estimating the significance of trade barriers is that those that are most visible are not necessarily the most important. In some cases - government purchasing policies, health restrictions, customs procedures, standards' specification, many types of subsidy - it is extremely

1. GATT, International Trade 1980/81, 1981, p.10. 
difficult to establish whether difficulties arise from deliberate attempts to discriminate against non-nationals, let alone to quantify the effects; yet it is in these areas of non-tariff barriers (NTBS) that there is currently much concern. By contrast, tariff questions have become less important and this reflects the fact that once the Tokyo Round cuts have been implemented the average nominal rate for industrialised countries will be a mere 6.5 per cent for finished-manufactures and 4 per cent for semi-manufactures.

4. For developing countries, the question of tariffs is not however a trivial one, despite the existence of tariff preference schemes whose declared aim is to allow developing countries tariff-free access on a preferential basis. First, there are some industrial products with tariffs significantly above the average and the items correlate closely with areas of developing countries industrial comparative advantage, and also with 'sensitive' treatment under Generalised System of Preferences (GSP) schemes. In many cases these items were also exempted from full, or any,cuts in the Tokyo Round: many textile and clothing items; shoes; cutlery; consumer electronics (though other exemptions and relatively high tariffs as on vehicles - mainly affect trade between industrial countries). second, there is evidence that tariffs on products of primary interest to developing country exporters are not only higher but were due to decline less rapidly under the Tokyo Round; though any overall assessment is difficult because of the complexities of the various GSP schemes. ${ }^{1}$ Thirdly, there is tariff escalation on processed goods, giving rise to somewhat higher rates of effective, than of nominal, tariff protection. GATT's own assessment is that tariff escalation on products of interest to developing countries was not eased under the Tokyo Round although the problem has been posed for many years ${ }^{2}$. We shall nonethelessin this paper, concentrate on NTBs, looking in particular at those which involve quantitative control of imports.

1. GATT, The Tokyo Round of Multilateral Trade Negotiations, Vol.2, January 1980.

2. Ibid. 
The Extent of Restrictions

5. Methodologically, the simplest way to monitor protection in all its forms - though one still fraught with problems - is to accumulate an inventory of changes in trade barriers using GATT, IMF and national data. ${ }^{1}$ Franco notes that it is "unlikely to be a statistical artifact" that EEC safeguard, surveillance and antidumping actions rose from 24 in the four years 1971-74 to 41 in 1977 and 94 in the first eight months of 1978 (of which 74 related to textiles and steel). ${ }^{2}$ other surveys have shown evidence of an upsurge in petitions to, and affirmative findings by, the US International Trade Commission (ITC) (though many were then overruled by the President). ${ }^{3}$ There has also been a spate of antidumping and safeguard actions in smaller OECD countries. Straight counts may give some indication of trends over time but they could also be very misleading. They do not differentiate trivial from major restrictions, either in respect of products or suppliers.

6. One relatively sophisticated variant of the inventory method was applied by Olechowski and Sampson in comparing the extent of protection in the EEC, the USA and Japan. ${ }^{4}$ They used official, government and GATT notifications to estimate the frequency of incidence of NTBS at a very disaggregated product level. The frequency was then expressed as a percentage of the number of product categories in 15 broad industry groups (that is, unweighted by trade values). Roughly 20 per cent of categories in the USA and EEC were found to be subject to controls, 5 per cent in Japan.

1. The main sources are GATT Surveys of Developments in Commercial Policy and IMF Annual Report on Exchange Restrictions. There is a recent review by the IMF in Trade Policy Developments in Industrial Countries, Occasional Paper No.5, Ju1y 1981.

2. J. Franco, Current Trends in Protectionism in Industrialised Countries: Focus on Western Europe in G.K. Helleiner et al. Protectionism or Structural Adjustment, Atlantic Papers No.39, 1980 .

3. James Riede1, Monitoring Trends in Protectionism, World Bank 1979. The main source for actions taken is US office of the Special Trade Representative: Trade Actions Monitoring System (various issues).

4. A. 01echowski and G. Sampson, Current Trade Restrictions with the EEC, USA and Japan, Journal of World Trade Law May/June 1980. 
Incidences substantially above this crude average of 20 per cent were found for chemicals (in the USA only), paper (in the EEC), and textiles, clothing and footwear (EEC and USA). Japan had relatively high protection of leather goods, chemicals, transport equipment and cement. Ninety per cent of the EEC controls discriminated between sources, but only 52 per cent of US controls.

7. A more up-to-date inventory for the late 1970s, also from the EEC, the USA and Japan, has been prepared by Gard and Riede1. 1 They found that outside of textiles, clothing and steel, there have been no significant official new barriers in the USA and the EEC while Japan appears to have been liberalising. They acknowledge that the story appears different if informal and unofficial restraints are considered. (One might add that a record only of official barriers is very flattering to Japan.) The same conclusion is reached by an IMF survey which also noted the rise in unofficial and secretive agreements, while this and other studies demonstrated widespread use of 'voluntary export restraints' (VERs) and 'orderly marketing arrangements' (OMAs).

8. Developing the same theme, GAT'T noted that there had been a growth of measures in what it calls the "grey areas" which "have been growing in number and frequency. That there has not been more open violence to the rules is also partly explained by the increasing resort to privately agreed and officially tolerated, if not promoted, restraints on trade and competition." 3 In the field of consumer electronics, for example, inter-industry VERs, rather than quotas, are the norm; these VERs replace, in some instances, expired patents which have limited the transfer of colour television technology. To take another "grey area", there has been strong pressure on retailers - especially in the USA and the United Kingdom - to

1. L.M. Gard and J. Riede1, Safeguard Protections of Industry in Developed Countries: Assessment of the Implications for Developing Countries, Weltwirtschaftliches Archiv, 1980.

2. B. Nowzad, The Rise in Protectionism IMF 1979 . T. Murray, W. Schmidt and I.Walker, Alternative Forms of Protection Against Market Disruption, Kyklos, 1978 .

3. GATT, International Trade 1980/81, p.11. 
acquire shoes and clothes from national manufactures for 'patriotic' reasons. In this, there is a hankering for the kind of unofficial NTB presented to importers by the allegedly impenetrable Japanese retail system and, to a lesser extent, the French. Yet another "grey area" is industrial subsidies which, in the mid-1970s, had increased to the point that they accounted for 6 to 7 per cent of GNP in the more extreme cases (Norway or Ireland) and over 2 per cent of GNP in most OECD countries. ${ }^{1}$ Not all of these subsidies were designed to influence trade performance but many did so, intentionally or not, and the evidence suggests that they have, in recent years, been directed not to 'infant' industries but primarily to those which attracted other NTBs. ${ }^{2}$ The potential damage to the system of international trade rules by subsidy proliferation is well exemplified by the current USA-EEC conflict over steel. And, as developing countries increasingly develop more varied exports, of engineering goods for example, they enter another "grey area": barriers to trade in the form of standards' specifications - which differ considerably between countries ${ }^{3}$ - public sector procurement policies and safety requirements whose trade implications are often secondary but nonetheless real, as is recognised by the existence of the new GATT codes.

9. If we ignore the "grey areas" for the time beine, it is possible to make a rough estimate of the amount of manufacturing trade which is 'managed' by importing countries through explicit NTBs. GATT's most recent figures (Table 1.1) suggest that of a total US $\$ 61.0$ billion of manufactures exported by non-oil developing countries to industrial countries in 1981 , about a third was in categories subject to severe quantitative restraints: US $\$ 17.5$ billion of textiles and clothing and US $\$ 2.2$ billion of iron and steel. other items, less seriously affected, are US $\$ 5.5$ billion of household

1. GATT, Adjustment, Trade and Growth in Developed and Developing Countries, GATT Study in International Trade, No.6.

2. G. de Carnoy, Subsidy Policies in Britain, France and West Germany in S.J. Warnecke (ed) International Trade and Industrial Policies, MacMillan, 1978.

3. Sir F. Warner, Standards and Specifications in the Engineering Industries NEDO, 1977 . 


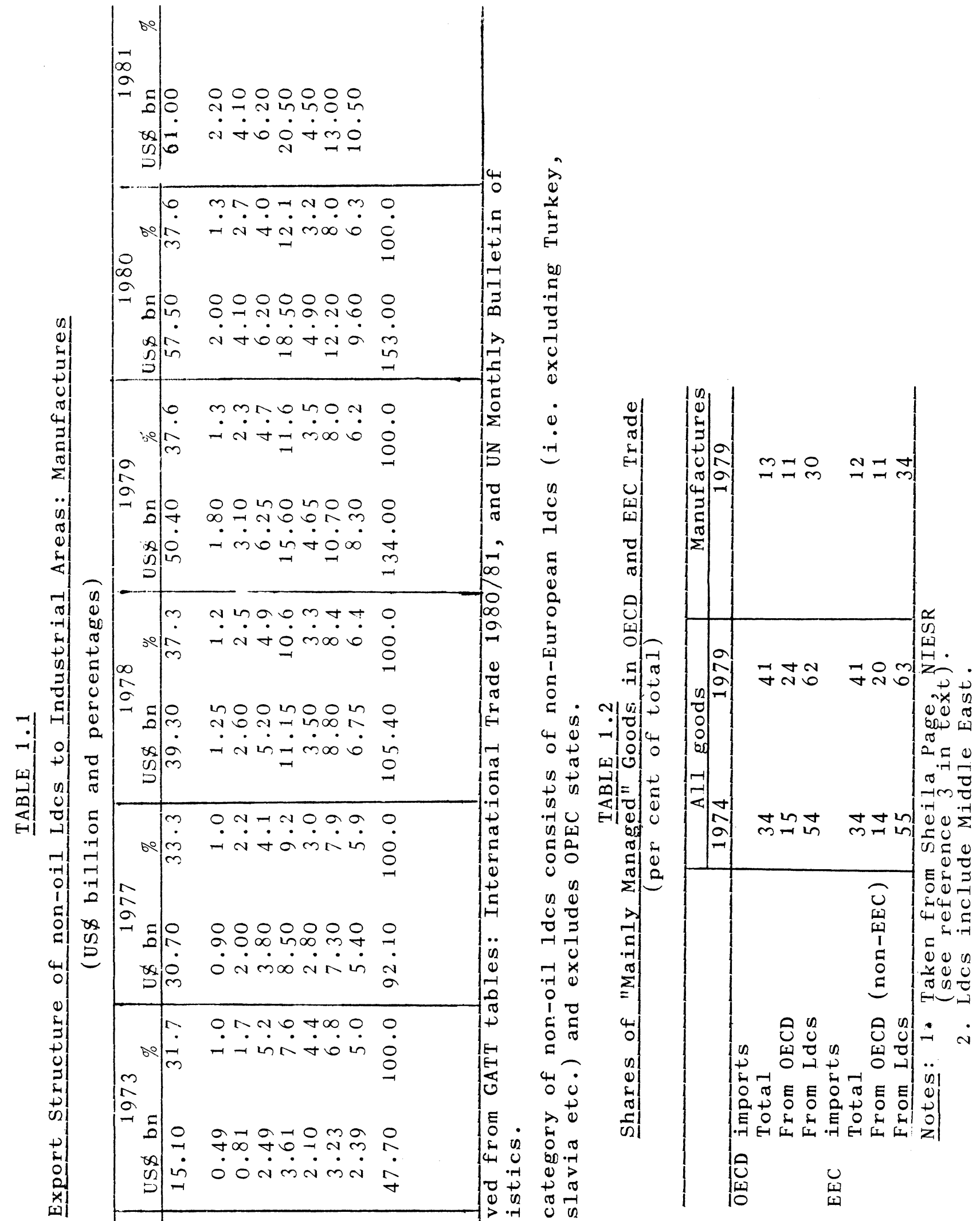


appliances and US $\$ 3$ billion of footwear. One important study has built up a more complex picture of the extent of trade management. Sheila Page estimated (on the strength of restrictions applying in 1979) that of manufactured imports into OECD countries 30 per cent from non-oil developing countries were 'managed' against 13 per cent from all sources (Table 1.2). The former figure - but not the latter - was increasing over time. ${ }^{1}$

\section{The Severity and Effects of Protection}

10. There is clear evidence that the extent of trade barriers in industrial countries facing developing country exporters of manufactures is greater than that facing industrial countries. The incidence is also more severe. We have already noted that the trade weighted - effective or nominal - tariffs facing many developing countries are greater than for developed countries even after preferences are allowed for, and in the Tokyo Round many high tariff items of concern to developing countries were exempted from full cuts. The severity of NTBS is however much more difficult to estimate. Roningen and Yeats tried to measure the effect of NTBS by directly comparing domestic producer prices with 'world prices' endeavouring, as carefully as possible, to eliminate quality and product differences. ${ }^{2}$ They found that, on this measure, the tariff equivalent of NTBs could be as much as 70 per cent for all imports (for Sweden and Japan) and 35 per cent for the USA. The price differential is, however, almost certainly an overstatement of protection and reflects other factors, including the different distribution mark-ups between home-produced and imported goods, and consumer resistance to imports: influences which will also be

1. Sheila Page, 'The Management of International Trade', in R. Major, ed., Britain's Trade and Exchange Rate Policy, Heinemann, 1979 .

The Increased Use of Trade Controls by the Industrialised Countries', Intereconomics, No.3, 1980 .

'The Revival of Protectionism and its Consequences for Europe', Journal of Common Market Studies, September, 1981.

2. V. Roningen and A. Yeats, Non-Tariff Distortions of International Trade: Some Preliminary Evidence, Weltwirtschaftliches Archiv, 1976 . 
different between countries. The study was, however, useful in suggesting not only that NTBs were probably very important as barriers but also that there was no discernible correlation between their level and either tariff levels or NTB incidence calculated by inventory methods.

11. Another, more reliable, method of estimating directly the tariff equivalent of NTBs is provided by quota premia. Where quotas are export administered and there is a free and efficient quota market, the premium gives an accurate measure of the tariff equivalent required to produce the same effect as the quota. ${ }^{1}$ Unfortunately, since quota markets fluctuate wildly, reflecting temporary variations in supply and demand, averaging is a dangerous exercise. Some detailed work done on textile and clothing exports to Canada does, however, suggest, very plausibly that, while a good deal lower than indicated by direct price comparisons, the tariff equivalent of quotas is often greater than tariffs themselves. The combined protection of tariffs and quotas can amount to well over 30 per cent - nominal tariff equivalent - for most clothing items and can reach over 70 per cent (in nominal terms). 2 The Australian Industries Assistance Commission has calculated nominal tariff equivalents of over 100 per cent in these industries, although that is not to suggest that Australia is more protectionist, merely that it is one of the few countries where a public body exists to analyse trade policy effects. 3

12. The cumulative effect of these relatively severe trade restraints in some product areas is to produce a bias in the protective structure of Western economies. A number of industrial cross-section studies of the levels, and changes in the level, of production variously measured - in Western countries now show that there is usually a strong correlation with those industry characteristics associated with developing country comparative advantage: labour

1. M.F. Mokre, Rent Seeking and Hong Kong's Textile Quota System, The Developing Economies, March 1979.

2. Glenn P. Jenkins, Costs and Consequences of the New Protectionism, North-South Institute, 1980.

3. Australian Industries Assistance Commission, Annual Report, 1980/ 81 . 
intensity; low wages; a high proportion of women or unskilled workers in the labour force; and numerous small nationally owned firms. ${ }^{1}$ Inevitably, protective barriers, selectively applied, will reduce flows directly and divert trade to countries less severely restrained. Developing countries will also be diverted into industries in which they have less of a comparative advantage and which provide fewer opportunities for employment creation. There is corroborating evidence that those areas which still remain largely unprotected are those in which transnational corporations have strong interests in keeping freedom of trade; and while developing countries may find advantage in - say - a sub-contracting role, this will then involve trade management problems of a different but real kind. ${ }^{2}$

13. What, then is the effect on developing country exporters? The World Bank, which uses changes in market penetration in industrial countries from developing countries as a proxy for the effects of protection, notes that the growth rate of market penetration for manufacturing fell from 13 per cent per annum in the period 1970-74 to 7 per cent per annum in 1976-79, while acknowledging that it is difficult in practice to separate out the influence of slower market growth from that of market access barriers and that the rate of market penetration is not an ideal proxy for the degree of protectionist resistance. ${ }^{3}$ There is, from the same data, no clear cut evidence of some Western countries being 'more protectionist' than others: penetration rates are growing most slowly in some developed countries where the levels are highest (Sweden, Belgium and United Kingdom); in Japan, where few formal tariff or NTBs are recorded, the level and growth of penetration is relatively low (Table 1.3). There is rapid growth in some unfamiliar areas - machinery, printing, china and glass, chemicals - which may suggest some conscious diversification into unprotected categories as well as a more varied expression of comparative advantage (Table 1.4).

1. The evidence is summarised in K. Anderson and R.E. Baldwin, The Political Market For Protection in Industrial Countries: Empirical Evidence, World Bank Staff Paper No.492, 1981.

2. The line of argument is developed by G.K. Helleiner in Transnational Enterprises and the New Political Economy of US Trade Policy, Oxford Economic Papers, March 1977, and Intra-Firm Trade and the Developing Countries: An Assessment of the Data, Journal of Development Economics, 1981 .

3. H. Hughes and J. Waelbroeck, Can the Growth of Developing Country Exports Continue in the 1980s, World Economy, 1981. 


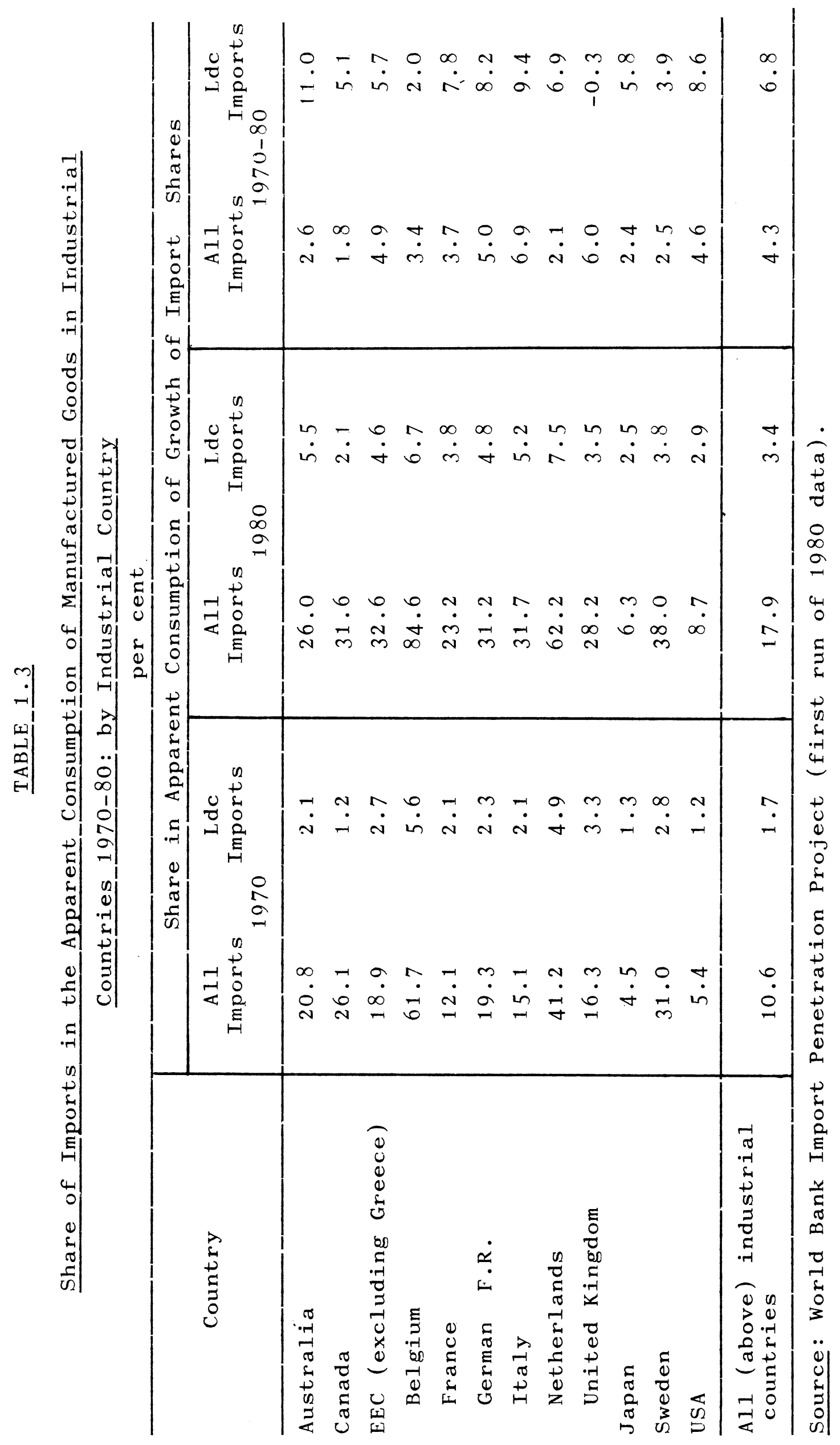




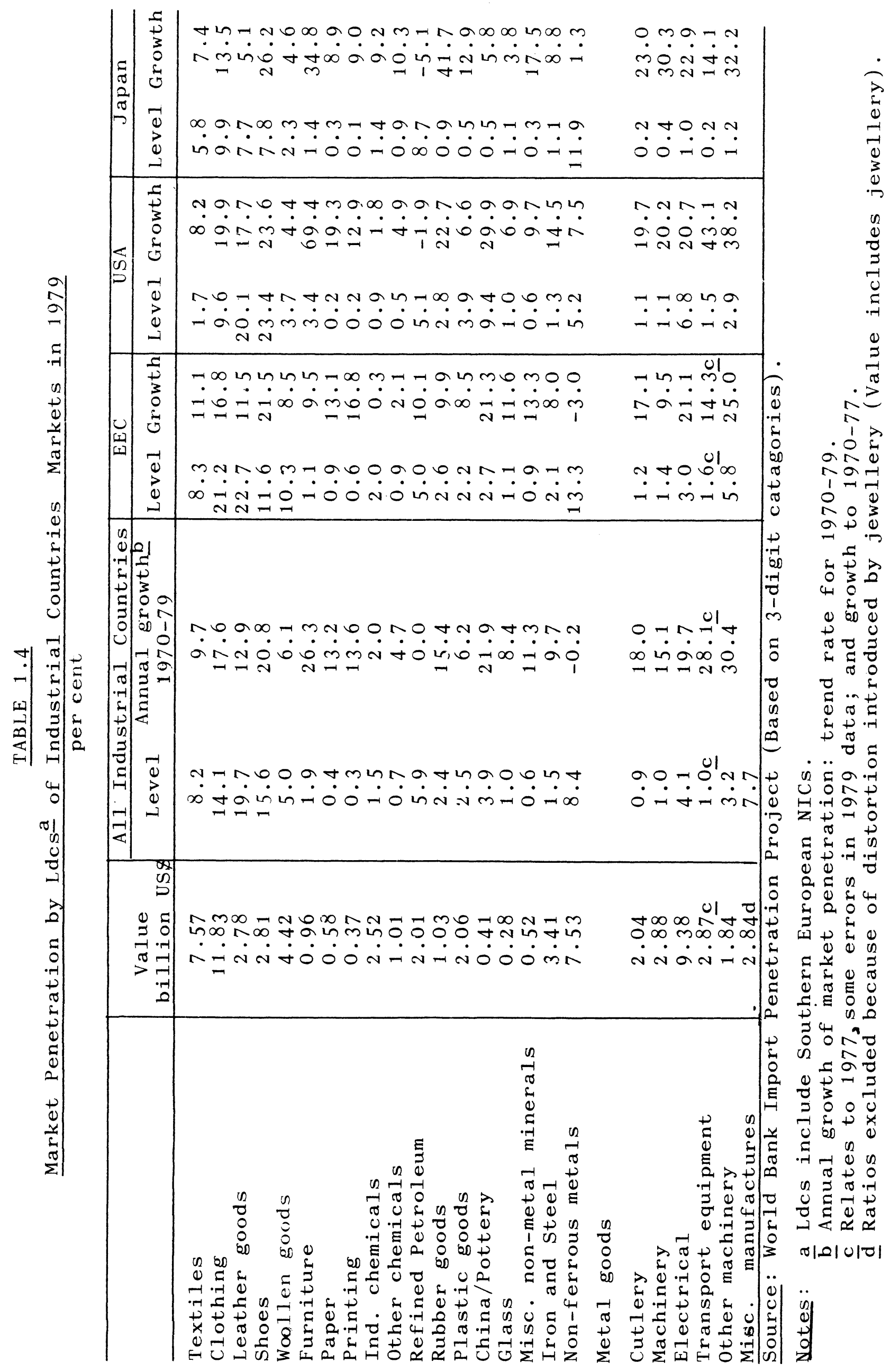


14. There appears to be little data available on how individual developing countries are affected, though in many cases-especially those which are mainly textiles exporters - a majority of manufactured exports is covered by protective measures in important markets. Often it is the relatively new entrants to world markets for manufactures who are most seriously affected, since they are unable to build up worthwhile volumes before restrictions are imposed. It has been argued that where industrial countries refuse to cede a growing market share to developing countries, a 'fallacy of composition' effect will increasingly operate to prevent these countries - usually the poorest - following in the path of newly industrialising countries (NICS). ${ }^{1}$ There also appear to be variations amongst the NICs. Hong Kong and Singapore seem to be much less affected than Republic of Korea or Taiwan; Mexico less than B̈razil. In the case of Singapore (and Mexico because of its border zone) a particularly high proportion of exports is sold through transnational corporations, especially in electronics products. Hong Kong traders now have a very varied export mix outside of textiles and clothing (Table 1.5) and have been particularly successful in identifying new market opportunities for radios, watches, plastic and leather bags, toys and games, wigs, umbrellas - where there is little protectionist resistance. Both Singapore and Hong Kong are, of course, open unprotected economies with large imports and this may have further weakened hostility to them.

\section{Textiles, Clothing and Footwear}

15. The textiles and clothing family of industries has provided most developing countries with their earliest experience of manufactured exports and it remains a major component of the total: 11 per cent of al1 their exports in 1979, 25 per cent of their manufactured exports and 20 per cent of their manufacturing exports to developed countries. This trade has not, however, developed under free market conditions but under some degree of quota restraint, latterly under the Arrangement Regarding International Trade in

1. W.R. Cline, Can the East Asian Model of Development be Generalised? World Development, Vol.10, No.2, 1982. 


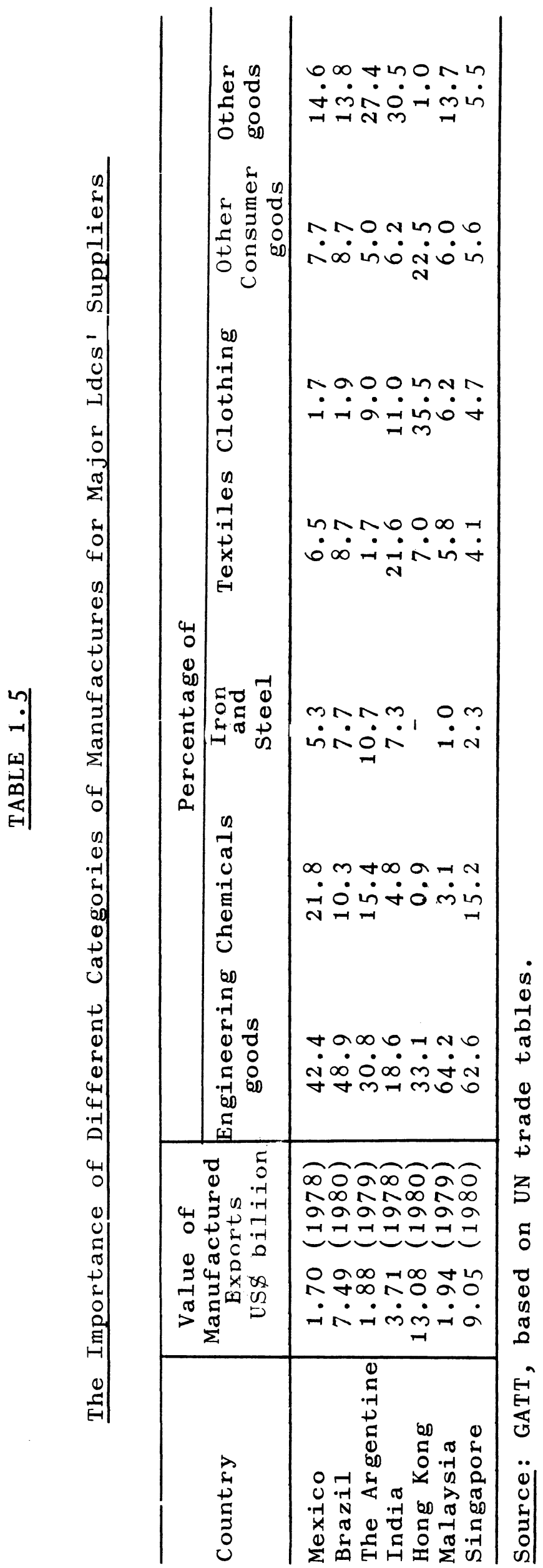


Textiles (MFA) of 1974 and earlier under the Long Term Arrangement regarding International Trade in Cotton Textiles (LTA) of $1962 .{ }^{1}$

It is the developing country experience of the MFA, particularly in the period after 1977 - with expanding country and product coverage, diminishing growth provisions, growing complexity and rigidity and apparent permanence - which has contributed most to their apprehension about 'protectionism'.

\section{Trade Trends}

16. Although exports of textiles and clothing are important for a growing number of developing countries and are a substantial influence in the markets of industrial countries, we need to keep the relative proportions in perspective. The share of developing country textiles and clothing exports in the markets of industrial countries was only around 10 per cent in 1979 , and 14 per cent for clothing alone (in value terms) - see Table 1.5. The degree of overall penetration is somewhat higher in smaller OECD economies (Sweden and Netherlands, 20 per cent, Australia, 18 per cent) and in German F.R. and the United Kingdom ( 17 per cent and 13 per cent) than in the USA, France or Japan (a11 6 to 7 per cent); but even the most open of these economies is very far from having ceded the bulk of its market to 'low cost' imports. Industrial countries still account for almost 70 per cent of the textiles' exports of all market economy countries and run a trade surplus with the rest of the world - though a declining one - in textiles (Table 2.1). In most types of textiles, excepting the weaving of 'cotton and allied' textiles, and even in some areas of clothing, such as hosiery, developing countries hardly feature as major international competitors. Their competitive advantage is more limited.

17. It can however be said that, even taking into account possible technical developments in the cutting and sewing operations of the garment industry, low wage economies wi11, under competitive conditions, continue to enjoy a significant cost advantage in many branches of clothing. The reverse is probably true in textiles

1. There is a comprehensive review of the history in D. Keesing and M. Wolf, Textile Quotas Against Developing Countries Thames Essay, No.23, TPRC, 1980. 


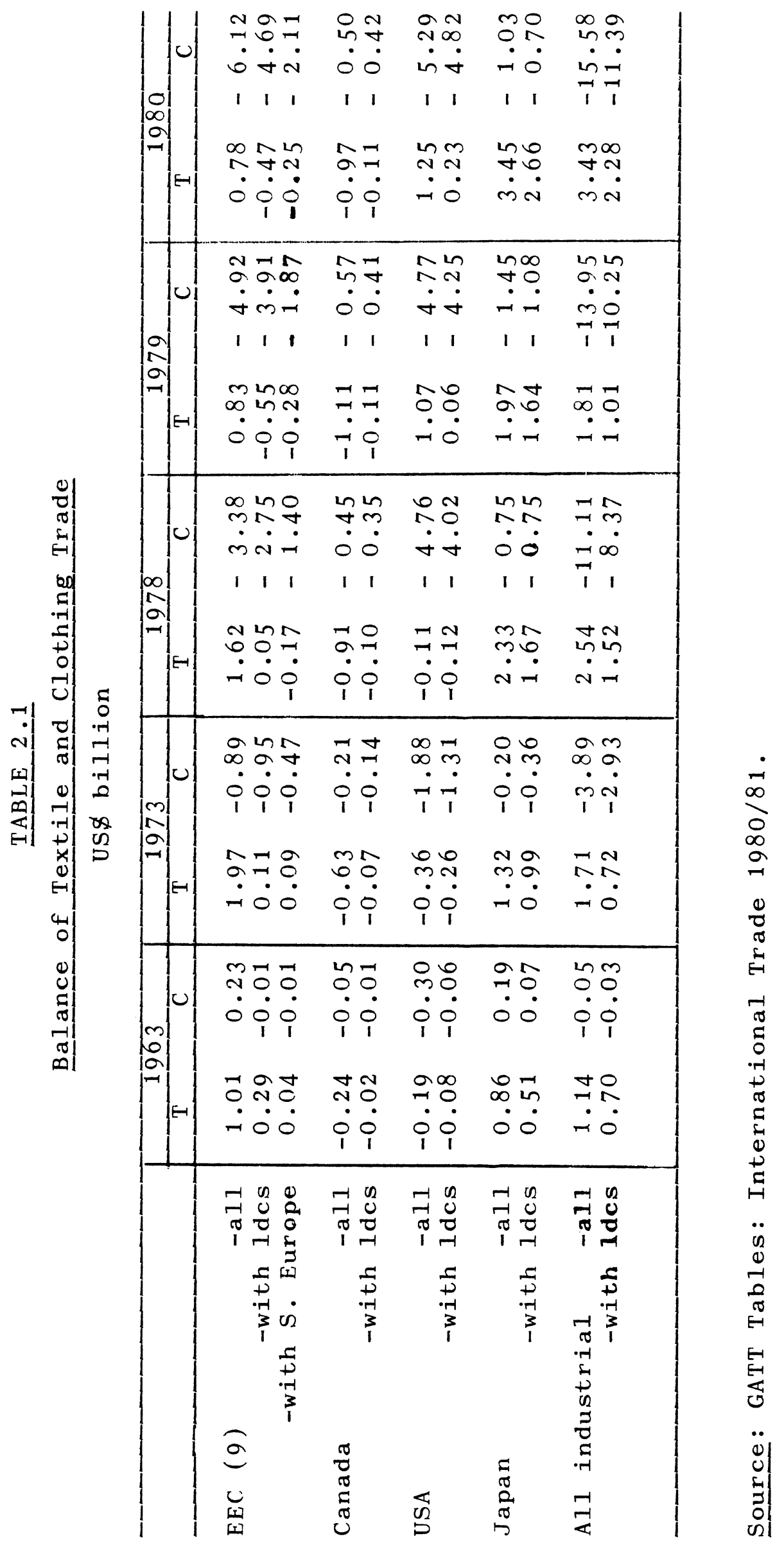


where the evidence suggests that the process of capital deepening achieved by investment in new generations of high-speed looms and knitting machines - has given the industry in some industrial countries a ratio of fixed capital to labour employed somewhat in excess of the manufacturing average. ${ }^{1}$ It is a moot point as to whether companies took this route in response to the competition they faced from developing countries or because the existence or prospect of protection made investment of this kind commercially attractive. In any event, heavy investment in labour-saving equipment has not yet given textile industries in industrial countries sufficient self-confidence to operate without protection under the MFA (that is, of yarns and fabrics as well as garments). 2

\section{Extent of Protection}

18. The degree of coverage of developing country exports to industrial countries by quotas, or tariffs well above the average, is very comprehensive. The American Apparel Manufacturers acknowledge that 85 per cent of the total US apparel trade is controlled through bilateral quotas while UK sources have claimed that around 98 per cent of 'low cost' textiles or clothing - including that from EEC applicant members - is now covered by MFA quota arrangements (the EEC's 'trigger' mechanisms are designed to ensure 100 per cent potential coverage). 3 In some cases - Canada and some Scandinavian countries all trade flows from developing countries including those of little more than one hundreth of one per cent of overall imports, are subject to quotas. With the exception of Japan and Switzerland, all industrial countries apply quotas or prohibitive tariffs and neither of those two countries have high penetration for other reasons. Few developing countries, even amongst the smaller suppliers, are now exempt from quotas while there are 'consultative'

1. There is a detailed analysis of these issues in an unpublished report by the OECD; Structural Problems and Policies to the OECD Textile Industries, 1980.

2. The experience of industrial countries is very different however, with German F.R. , the USA, Switzerland, and Japan doing rather better in this respect than the UK, France, Canada or the Scandinavian countries. See Geoffrey Shepherd, Textile Industry Adjustment in Developed Countries, Thames Essay No.30, TPRC, 1981.

3. AAMA statement on 30/11/79. A good UK source is Department of Trade The Government and the Textiles Industry, September 1980 . The system is described more comprehensively in V. Cable An Evaluation of the Multifibre Arrangement and Negotiating Options Commonwealth Economic Papers No.15, 1981. 
agreements for potential but not actual exporters such as Bangladesh. The only significant exception now is 'offshore' assembly, for example by US firms in the Mexican border zone and some German and Dutch firms in Eastern Europe and North Africa. There are also separate protective arrangements for textile products not covered by the MFA. Jute fabrics, yarn and products have long been protected in the EEC, the main market for India and Bangladesh (the United Kingdom has retained jute quota protection since World War II, one of the incidental side effects being the precipitation of technological changes in the industry which have fundamentally altered its previously labour intensive character). ${ }^{1}$

19. The quota controls are not only comprehensive but discriminatory, and do not in general apply to trade between industrial countries (exceptions are controls on Japanese exports to the USA and Canada, very shortlived UK quotas on US synthetic yarns, some French surveillance of other Community imports and global quotas operated under Article XIX by Norway). Tariff coverage is also relatively high and textiles and clothing experienced some of the smallest cuts in both Kennedy and Tokyo Rounds. Under The GSP schemes, product exclusions or quantitative limitations on duty-free access are consistently more severe in the textiles area. The high tariffs and GSP limitations are significant for the USA and Canada ( 21.1 and 21.2 per cent nominal tariffs respectively for clothing, post-Tokyo Round, as against 5.6 and 9.1 per cent for all manufactures) and for Australia which relies heavily on tariffs for protection. The elaborate GSP limitations, especially those in the EEC, represent a substantial degree of overkill since, clearly, preferential tariffs are largely redundant where quantity restrictions are used to regulate the trade of all potential beneficiaries.

\section{The Effects of Textiles Protection}

20. Despite the popular picture of 'floods' of cheap imports from developing countries, the evidence suggests that under the MFA quotas have, in fact, prevented developing countries realising the scope "for a greater share for them in world trade in these products" (Article 1:3). Their share of world trade has now stagnated at

1. The jute story is described (mainly as it affects the UK) in S. McDowal1 and P. Draper, Trade Adjustment and the British Jute Industry: A Case Study, ODI in conjunction with the Fraser of Allander Institute, 1978 . 
around 26-27 per cent for five years. GATT data also suggests that developing country signatories of the MFA have experienced in this period a declining share of the imports of developed country members, especially in the EEC (mainly at the expense of Southern European OECD countries). The picture is even clearer if we consider incremental trade. Developing country members achieved 62 per cent of the incremental share of clothing imports and 36 per cent of 'textiles' imports in the 1973-76 period, but on1y 43 per cent and 24 per cent respectively, in the 1976-79 period (Table 2.2). The most obvious explanation for the trends observed is that a tightening of quotas on MFA developing country members in the late 1970 s has led to a process of export substitution, a switching from restrained developing country to non-restrained developed and developing countries suppliers.

21. The other criterion against which developing countries judge the experience of the MFA is its declared objective to "secure a substantial increase in their export earnings from textile products", which was to be achieved by guaranteeing 6 per cent real import growth within restrained categories. Data published by the Commission of the European Communities, however, acknowledged that in the 1976-79 period developing country exporters participating in the MFA achieved an average annual growth in volume of only 2.4 per cent under bilateral agreements and "low cost suppliers", as a whole, experienced growth of 4 per cent (in comparison, exports to the EEC of MFA products from industrial countries grew by 9.9 per cent). ${ }^{1}$ Developing country textile and clothing exports to the USA grew in volume terms by only 3.8 per cent per annum in the 1971-79 period taken as a whole, although fell between 1976 and 1979. GATT figures for the 1976-79 period show that the real (constant price) growth rate of textile and clothing imports into industrial countries from all developing countries was 4.6 per cent (for both categories, jointly and separately), as against 8.4 and 9.2 per cent from Southern Europe and 6.5 and 5.3 per cent from other industrial countries (Table 2.3)

1. The Commission of the European Communities, The Multifibre Arrangement: Background Report, ISEC/B 43/80, September 1980 . 


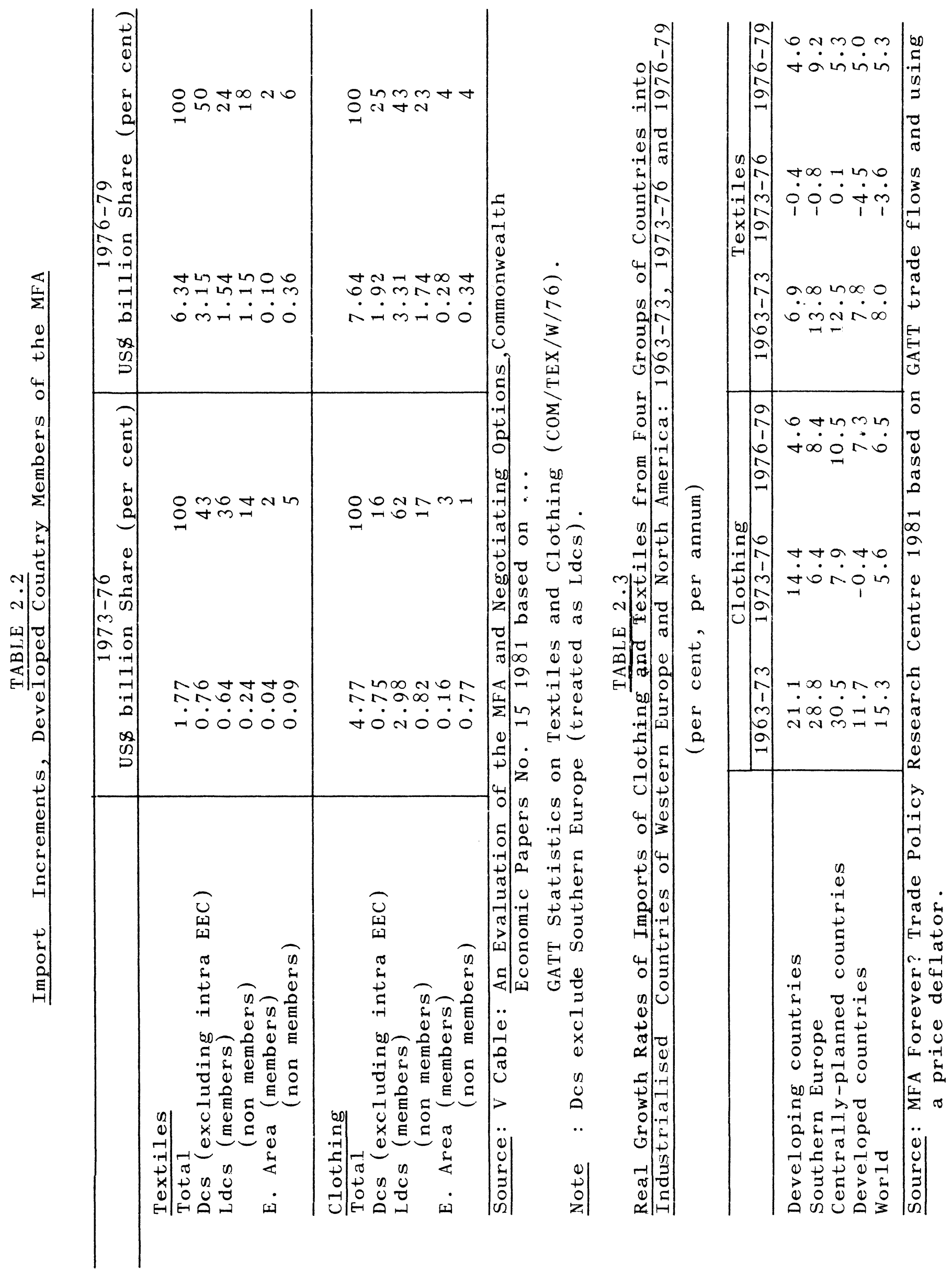


22. Some developing exporting countries find the quotas less restrictive than others. Many individual quotas are unfilled because of internal supply problems, disorganised quota markets or, simply, the inability of a system of detailed quantitative planning of international trade to accomodate rapidly changing fashion and changes in competitiveness. Nonetheless, in the countries that have geared production primarily to exports - mainly Hong Kong, Republic of Korea and Taiwan - import quotas are virtually always filled. Countries which have their export earnings and employment generating prospects most severely inhibited by quotas are the poorer 'labour surplus' economies - Philippines, India or Sri Lanka, for example - in the field of garments (if not textiles).

23. The MFA was originally envisaged as a means of heading off protectionism and a basic objective was to "achieve the expansion of trade, the reduction of barriers to such trade and the progressive liberalisation of world trade in textile products". But, in acceding to the MFA, developing countries also made important concessions: derogation from the GATT principle of non-discrimination; acceptance of an ill-defined concept of 'market disruption' resulting in 'serious damage'; explicit recognition of smal1 developed countries' right to 'minimum viable production'; and, by operating in a GATT framework, they gave up the weapon of retaliation, accepting that negotiated agreements with quotas administered by themselves were preferable to unilaterally imposed import quotas. In 1977 , renegotiating the MFA under strong duress, they accepted a further change, this time from the original MFA, in an amending protocol permitting "reasonable departures", albeit temporary and jointly agreed. Following this step, a set of bilateral agreements was concluded which reduced considerably the rate of increase in the volume of imports either by specifying lower growth in 'sensitive' categories or by reducing flexibility.

The Post-1981 MFA

24. The future nature of restrictions under the MFA will depend primarily upon the bilateral agreements negotiated under it. The most important of these - with the EEC and the USA - were still being negotiated, at the time of writing, to cover the period after 1982. There were, however, some significant changes also in the 
protocol (or annexes to it) which was negotiated to extend the MFA until mid-1986. The objectives of the original MFA are reaffirmed. But, some changes are of a more restrictive character, while others are potentially liberalising. The balance to be struck between the sets of provisions will emerge in the course of the bilateral negotiations. The 'reasonable departures' provision from the 1977 protocol has been dropped. There is also reference to a strengthening of the definition of market disruption with an obligation placed on the importing country to provide additional factual justification and provision for closer monitoring by the Textiles Surveillance Body (TSB). To be set along side these innovations is a new 'anti-surge' provision for action against sudden increases (over 10 per cent per annum)arising from past under-utilisation of quotas (albeit with compensation to exporters). Another feature is introduced obliquely through a reference to 'dominant' suppliers but separate communications between the EEC and Hong Kong, Republic of Korea, and Macao make it clear that their quotas will, in particular, be cut back.

25. Any expectations that the protocol might herald an improvement in the position of textile exporters have to be set alongside the fact that protectionist attitudes in industrial countries are hardening, even amongst Ministers supposedly committed to free trade policies. The prospects for liberalisation of the MFA system are worsening. We should note, in particular, how the powerful combined influences of recession in Western economies and skilful and persistent lobbying by the European textiles lobby, in particular, now threatens to create an even more protective set of arrangements. In 1980 the Commission of the European Communities pronounced itself satisfied that "the rates of growth of imports from the countries covered by the policy have been reduced and a stable trend established while the community global ceilings have been observed", while Commissioner Davignon noted that "over the past few years the MFA has worked vis-a-vis the developing countries". ${ }^{1}$ British trade minister and officials who, with the French, led the moves to toughen the MFA in 1977 acknowledged that the resultant controls

1. Commission of the European Communities, Report, $\operatorname{COM}(80) 438$. 
were highly effective: even "savage". 2 Yet the EEC - and particularly the United Kingdom, France and Italy - now threatens to withdraw altogether from the MFA unless the bilateral agreements being negotiated for the post -1982 period reduce substantially the overall level and growth of imports from MFA suppliers. The governments concerned are already under pressure from their textile lobbies for not being 'tough' enough.

\section{Evaluation}

26. The central intellectual justification for sectoral protection has been the concept of temporary 'breathing space' in which industries in relative decline can be given some time to cope with market adjustment pressures. After numerous extensions of "temporary" arrangements over a period of more than twenty years there is the danger that protection accorded by the MFA is becoming permanent. This contrasts with the declared objectives of the MFA (Article 1:4) that adjustment should be assisted by policies "required by changes in the pattern of trade in textiles and in the comparative advantage of participating countries, which policies would encourage businesses which are less competitive international1y to move progressively into more viable lines of production or into other sectors of the economy and provide increased access to their markets for textile products from developing countries". Under the new protocol to the MFA, 'adjustment' is to be monitored more assiduously and there is even reference to a phasing-out of 'restraints'; but neither is given firm determination.

27. Many of the worst features of present arrangements derive from the inflexible specification of enormous numbers of individual quotas. This partly arises because of the proliferation of product quota categories (over 130 in both the EEC and the USA) and the differential sensitivity applied to each. In addition, there has been a growing tendency for importing countries to ignore the MFA's injunction to allow "substantial flexibility", incorporated in swing (between products), carry-forward and carryover (between years) provisions. The USA has used cuts in swing and carry provisions as the main weapon in its 'anti-surge' action against major suppliers, reopening, in several cases, existing agreements.

1. Statement to United Kingaom Parliamentary Select Committee $8 / 3 / 81$. 
Other importing MFA members - Canada, Sweden, Finland - have eliminated or cut flexibility provisions in bilateral agreements. The adoption, now, of an 'anti-surge' mechanism within the MFA will further limit flexibility in the case of quotas. The objective, clearly, is for the use of flexibility provisions as a device to cut overall import growth, but one effect is seriously to erode the responsiveness of the textile trade to market forces, and, in particular, to demand changes caused by fashion. The same objective also probably underlays the ranking of products by sensitivity with some, in the EEC, permitted an annual real import growth of under 1 per cent after 1977. Its incidental effect has been to accord maximum protection to the least efficient sectors within the industry. A further element of inflexibility in the EEC is the system of member state quotas superimposed on Community quotas for 'sensitive' items, according to a standard formula which ignores variations in market demand.

28. It was originally envisaged in the MFA that, within a framework of controls, importing countries would "provide more favourable terms (for developing countries) with regard to such restrictions... than for other countries". In practice the reverse is the case as we have seen from the trade statistics: developing countries in general and MFA signatories in particular have experienced less favourable treatment than other suppliers. The most explicit acknowledgement of this discrimination is the system of 'global' quotas applied by the EEC on 'sensitive' products to cover 'cumulative market disruption' by all 'low cost' suppliers (but not others). Within MFA negotiations it has also been a declared objective to favour small and new suppliers and - less formally the poorer developing countries (Articles $6: 2$ and 6:3). In fact, small suppliers have been affected by quotas imposed on specific trade flows of well under 1 per cent of imports, preventing any sort of scale of operation from being established; while the "trigger mechanisms employed by the EFC are designed to ensure that growing but small quantities ( 0.2 per cent of imports of 'sensitive' items) can be quickly acted upon. The poorest countries - India and Pakistan for example - enjoy no preferential status and most of their handmade textile items are now subject to quota controls because of disagreement over the authenticity of handloom certi- 
fication (or possibly because importing countries are in any event no longer willing to accomodate more-than-negligible volumes of handmade items).

29. One reason why textile exporters have, until now, accepted a high degree of trade regulation and limitation on market access is that the MFA did offer, at the outset, the prospect of reduced uncertainty and some clearly designed rules and obligations. Bilateral negotiations have certainly led to many stable four or five-year agreements, but there have been increasingly capricious and unpredictable elements. Perhaps the most important is the re-opening, annually, by the USA of agreements with major suppliers as part of its 'anti-surge' action; a precedent widened in significance by the incorporation of 'bilateral consultation' provisions (for 'anti-surge' action) in the post-1981 MFA. The use of the "trigger" mechanisms by the EEC has also created uncertainty over whether, and if so when, quotas will be imposed. The 'reasonable departures' formula in 1977 ushered in a period of innovation in protective devices within bilateral agreements which has certainly not ended with the formal lapse of the formula. The Textile Surveillance Body has not been allowed to develop judicial or arbitrating functions in a way which could have restored a sense of order. and legality to proceedings.

30. This picture is a largely negative one, although it could be argued that, without the MFA, the restrictions would be worse, and even less disciplined. This is, however, water under the bridge and it should now be possible to envisage a gradual evolution to a more liberal and genuinely multilateral arrangement later in the 1980s. The MFA itself provides for such an arrangement were it possible to reinstate the primacy of multilateral safeguard procedures under a GATT safeguard code, rather than giving overwhelming emphasis to bilateral solutions. The issue is not, however, primarily legal or administrative but economic and political; namely, whether industrial countries will now - after a long period of protection designed to cushion the adjustment costs of import competition - allow the protective arrangements to be dismantled in stages, recognising instantaneous liberalisation to be an unrealistic goal. 
31. This industry has some of the same characteristics of the clothing industry: the major operations in shoemaking involve labour intensive methods and batch rather than mass production processes. 1 Some developing countries should enjoy an advantage in labour costs. The growth of developing country penetration of the markets of industrial countries has been very rapid - by over 20 per cent per annum in the EEC, USA and Japan - and the level of penetration is approximately 16 per cent overall in value terms. Market penetration has gone particularly far in the USA (24 per cent by value in 1978 and 1979). Developing countries have built up exportsinitially mainly in non-leather footwear - slippers and shoes with textile and plastic uppers. There is, however, a growing share of leather shoes - particularly from Brazil and Republic of Korea - which are of relatively high quality.

32. The rapid growth of footwear imports has led to strong demands for controls in both the USA and Europe. The largest importer is the USA and an attempt was made in 1977 to restrain its imports through OMAs with Republic of Korea and Taiwan (on non-rubber footwear). ${ }^{2}$ overall, imports have subsequently stabilised at around the 1977 level ( 375 million pairs) and import penetration (in terms of quantities) stabilised at around 50 per cent. However, within these limits, imports from Republic of Korea and Taiwan were halved while those from Hong Kong and Philippines rose by 250 and 1250 per cent. As footwear was being re-rcuted and finished in countries outside of quota control the US government has sought to stop this trade through 'certificates of origin'. The exports also solight to offset the restrictive effect of the quota by shipping uppers without soles and switching to unrestrained rubber shoes. The Reagan administration subsequently accepted a recommendation by the US/ITC not to extend the OMAs for Republic of Korea beyond mid-1981. The decision was regarded as a step towards trade liberalisation.

1. M. Szenberg, J. Lombardi and E. Lee, Welfare Effects of Trade Restrictions: A Case Study of the US Footwear Industry, Academic Press, 1977 .

2. The background is described in J. Mutti and M. Bale, output and Employment Changes in a Trade Sensitive Sector: Adjustment in the US Footwear Industry, World Bank Staff Working Paper, No.430. 
33. There is currently more pressure in the EEC for increased protection of the footwear industry. The European Federation of Footwear Manufacturers is seeking an MFA-type arrangement covering world trade as a whole. EEC imports from developing countries have recent $1 y$ risen rapidly - from 235 million pairs in 1978 to 320 million in 1980 ( 55 per cent of all imports from outside the Community). The main growth has been of slippers from China (P.R.) and of non-leather shoes from Republic of Korea and Taiwan. So far, action has been mainly confined to specific member states. France, the United Kingdom and Ireland have negotiated bilaterally or imposed quotas on imports from Republic of Korea and Taiwan. There are also widespread controls and extensive use of anti-dumping duties on imports from centrally planned economy countries. Tariffs are the main instrument used at Community level. Footwear duties are 8 per cent (leather) and 20 per cent (non-leather). All footwear is treated as highly 'sensitive' in the GSP and multilateral tariff cuts were not conceded in the Tokyo Round.

34. The level of protection is probably more severe in other OECD countries. Japan has a tariff on leather footwear of 27 per cent (and also strict quotas). Australia has a tariff of 34 per cent on leather shoes. Canada has quotas which were applied under Article XIX in 1977. Taking industrial ccuntries together, however, the coverage and intensity of restrictions are generally rather less than for clothing and textiles and appear to provide for some continuing import growth.

\section{Engineering Goods}

35. The category of goods described as 'engineering' is vast and variegated, so generalisation is dangerous. The rapid displacement of mechanical by electronic processes is, moreover, changing its character away from a traditional concern with metal working skills. And, with major changes in methods of production and new products are coming new patterns of trade. It is in this broad and changing family of industries that world manufacturing trade, and developing countries manufactured exports, have risen most rapidly. Between 1970 and 1979 the share of all imports in the apparent consumption of industrial countries - that is, import penetration - rose by 8 per 
cent per annum in engineering as against 5.1 per cent per annum for manufactures as a whole while developing country penetration of the same markets rose by 21.8 per cent per annum.

36. The rapid growth has occurred from a very low base. The engineering exports of developing countries, even now, account for under 2 per cent of apparent consumption in industrial countries as against 3.4 per cent for all manufactures. At US $\$ 21.4$ billion in 1979 they were heavily outweighed by the reverse flow (of Us $\$ 121.3$ billion). Future potential is suggested by projections that on a fairly optimistic scenario for the 1980 s - developing country engineering exports could grow by 17 to 20 per cent per annum so as to constitute, by 1990 , almost half of all their manufactured exports, far exceeding the contribution of textiles and clothing; "reflecting expected rapid increases in the imports of consumer electronics, machinery, motor vehicles and ships from developing countries, in particular the NICs, as well as the further extension of the international division of production process with rising imports of parts, components and accessories of various engineering products". 1 Even with this projected growth, the imbalance in engineering trade between developed and developing countries could grow from US $\$ 90$ billion in 1978 to US $\$ 285$ billion in 1990 (in constant 1978 prices). Yet for developing country exports to grow at the projected rate requires an assumption of liberal market access.

37. Within the wide engineering category there is much country and product variation (Tables 3.1 and 3.2). Engineering exports already account for half or more of the manufactured exports of some of the more industrially advanced developing countries, for example,Singapore,Brazil and Malaysia. The share is large and growing for others - Republic of Korea,Hong Kong, the Argentine and Mexico while India has also built up substantial engineering exports in a short space of time. For several of these countries engineering exports are seen as a major means of diversifying from traditional textiles and clothing. A distinction needs, however, to be made between two types of engineering: the assembly of light engineering goods - radios, calculators, cameras, watches - and the manufacture

1. B. Balassa, Prospects for Trade in Manufactured Goods Between Industrial and Developing Countries 1978-90, Journal of Policy Modelling, September 1980. 


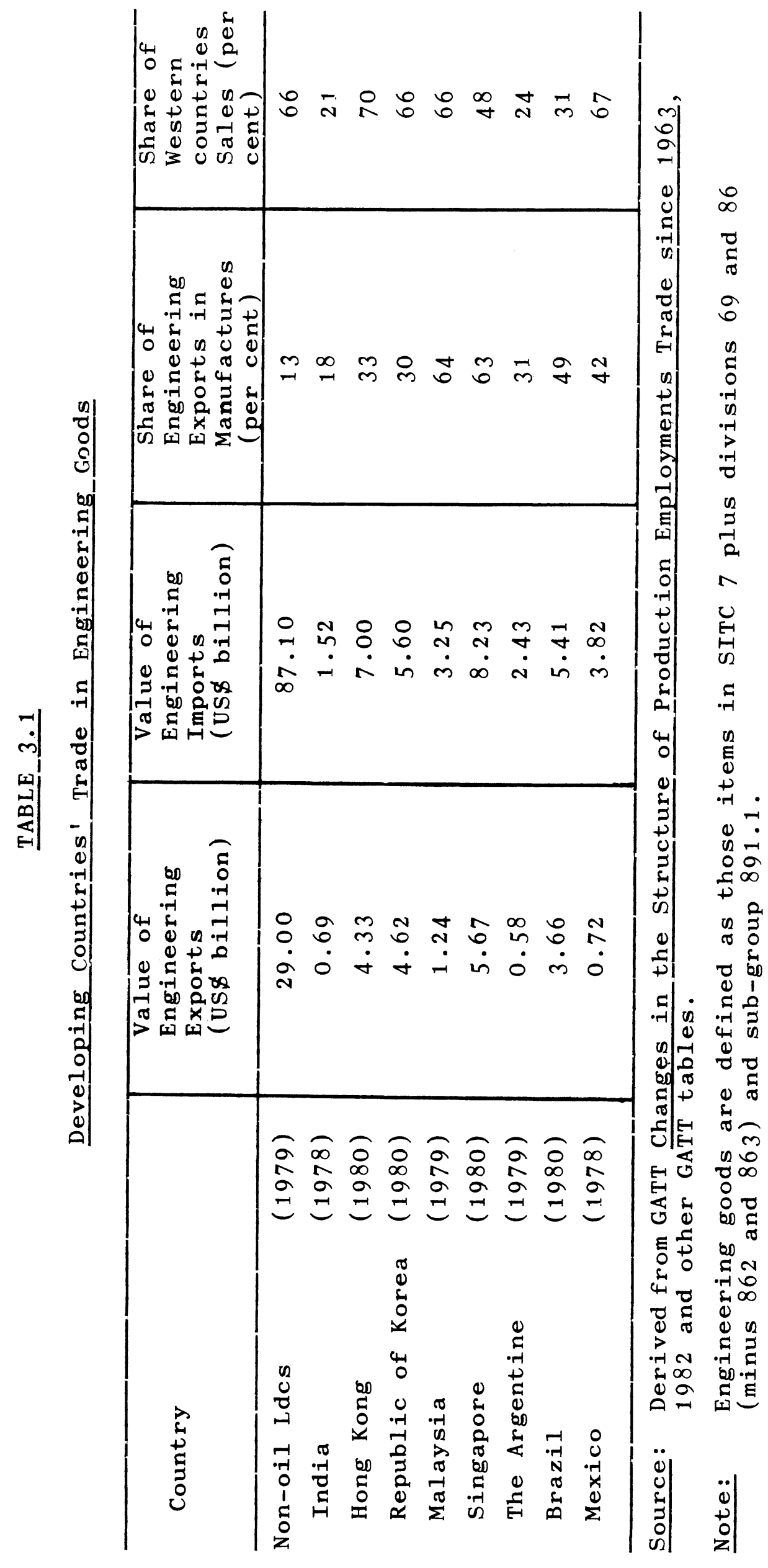




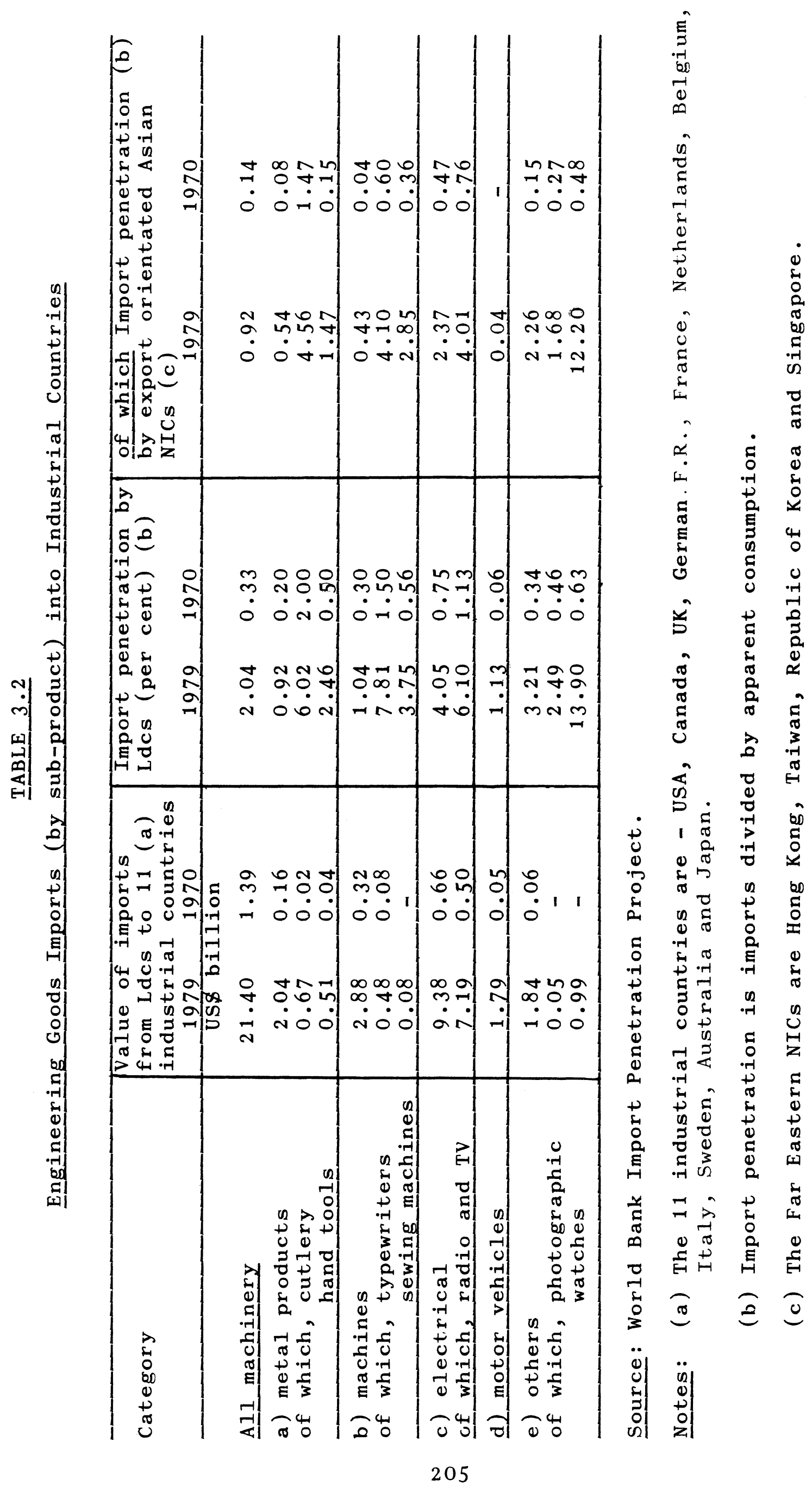


of more complex capital goods - vehicles and ships - often for export to other developing countries. Hong Kong, Singapore, Malaysia, Mexico and Republic of Korea have mainly taken the first route while India, Brazil and the Argentine have taken the second (although Republic of Korea is well represented in both areas). These two routes to the development of engineering exports represent different aspects of developing country comparative advantage. The first derives from the relatively abundant supply of low wage manual labourers, although no doubt skilled to a degree; the second draws upon the more sophisticated technological base now possessed by larger developing countries with a substantial experience of industrialisation. Protection in Western markets is naturally of more concern in the former, although developing country exports of the latter are affected by other forms of market intervention: protection in a wider sense, in the form of export subsidies or tied aid.

38. Despite the absence of formal quotas and tariff restrictions there are, in the area of engineering goods, problems of a different kind arising from technical standards and government procurement policies in the industrialised countries. Although these may not be protectionist in intention, they may in some instances considerably limit market access for competing imports.

\section{Metal Products and Light Engineering}

39. As can be seen from Table 3.2 there are two products here of real importance to developing countries: cutlery and hand tools. Cutlery, in particular, has seen major market penetration by east Asian exporters, in particular Republic of Korea - in the United Kingdom, German F.R., Italy, Sweden, Canada and Australia. Competition has, however, been in the narrow area of mass-produced stainless steel tableware produced in large mechanised factories with, paradoxically, the more labour-intensive specialist work, and silver plating, remaining in the developed countries, which have also retained the bulk of the production of most other products of this type (for example, holloware, razor blades and industrial cutlery). There have been demands from manufacturers for protection. Tariffs are well above the average - 17 to 19 per cent in the EEC - 
and were specifically exempted from Tokyo Round cuts; but the industry never acquired fully sensitive GSP treatment. In the USA, the President rejected an ITC recommendation for increased tariffs - the industry has enjoyed nominal tariffs of approaching 80 per cent. ${ }^{1}$ There are also several VERs operated in the United Kingdom, German F.R., Denmark, Norway and the Benelux countries. However, the VERs are of an unofficial industry-to-industry basis with Republic of Korea, and are not regarded as particularly effective (in the United Kingdom, they are negotiated by manufacturing firms with major importing interests). Protective measures, so far, fall well short of industry demands for quotas. There has been some growth of imports of handtools from Taiwan and especially India. Despite some protests in Europe from manufacturers about the volume of imports and low safety standards, the products face no significant tariff or NTBs. This is true also of other base metal products such as cooking stoves and metal plumbing fixtures: an ITC recommendation for protective action against imports into the USA of these products from Taiwan and Republic of Korea was rejected. Industrial fasteners (nuts and bolts etc.) have been more problematic, with Indian and Republic of Korean exports to the USA being the subject of countervailing action.

\section{Machinery and General Engineering}

40. Some NICs have begun to export significant volumes of heavier engineering items; mainly from Southern European countries (Yugoslavia and Spain) but also from Mexico, Brazil, India, Republic of Korea, Taiwan and Singapore. Some are sophisticated items embodied in turnkey plant projects in third (and third world) countries. There is also evidence that developing countries are beginning to realise a comparative advantage in labour intensive and technologically standardised products with low transport costs (heating and cooling equipment, pumps and centrifuges, mechanical handling equipment, and ball and roller bearings) and in producing machinery components and parts. ${ }^{2}$ Imports from developing countries

1. C. Pearson, Protection by Tariff Quota: Case Study of Stainless Stee1 F1atware, Journal of World Trade Law, 1978 .

2. Y. Kawaguchi, Non-electrical machinery exports by Idcs, World Bank, 1978 (Mimeo). 
of these products arise mainly from sub-contracting arrangements by Western companies which consequently view the trade favourably. There is, however, concern being voiced over NIC, as well as Japanese, competition in the field of machine tools - both standardised and more advanced microprocessor controlled lathes. 1

\section{Vehicles}

41. No significant friction has yet arisen over developing country exports of road vehicles and components. These exports are, of course, small in relation to world trade - about 1.5 per cent of the total. Another reason is that the major (NIC) motor industries which have any impact outside of narrow, national, import substitution are part of the multinational operations of the main Western and non-Japanese - manufacturers: VW and General Motors in Mexico; VW, General Motors, Ford and Fiat in Brazil and, in Europe, the Ford complex in Spain. Exports from these plants are mainly in the form of components - contributing towards the concept of "worldcars" - or, as finished vehicles, to other developing countries. Most forecasts for the 1980 s do not envisage the pattern greatly changing. 2 Although, on a 'product cycle' interpretation of trade patterns, the production of cars should become a 'mature' process which will drift to low wage cost locations, there is, to offset this, considerable progress being made in robotics and automated assembly. And economies of scale are a major barrier to entry for a new national car company divorced from transnational corporations. Some finished cars may be exported to Europe from Brazil but as part of a transnational corporation operation - by GM and Fiat since ford now incorporates Spanish made cars in its range. Past experience suggests that however much trade unions in Western countries may object to the growing multinational character of the car industry, the high level of reciprocal intra-industry trade makes it an unlikely candidate for national protection. By contrast,

1. The machine tool issues are reviewed in the UK and French case studies in Employment, Trade and North-South Co-operation (Ed. Geoffrey Renshaw), ILO, 1981 .

2. The structure of the industry and recent trends are discussed in the OECD Interfutures study document: "Long-Term Perspectives of the World Car Industries", 1978 . 
there is a network of quantitative restrictions and VERs applied to Japanese cars (and those from Eastern Europe - on a much smaller scale) and these could well be extended to other Asian vehicles in which European or US manufacturers did not have a stake either in ownership or in component supply. The only other likely candidate for future protection in the foreseeable future - if this argument is correct - is the Republic of Korean (Hyundai) Pony as sales are expanded in Europe. There may also be resistance to components manufactured outside the major companies as there is, at present, to tyres from Eastern Europe.

\section{Shipbuilding}

42. The question of protection, in the normal sense of border controls, does not usually apply in shipbuilding because of the nature of the shipping business. Nonetheless, this is an area where major trade distortions occur - in the form of subsidies, export credits, tax exemptions, government procurement and finance for research and development. Shipbuilding is an industry in which some of the more industrialised developing countries have made a substantial impact on trade, since the assembly operation is labour intensive, even if skilled and complex. The context is one in which the industry, world wide, is in a severe slump, production having fallen annually from 34.2 million gross registered tonnage in 1974 to 12.2 million gross registered tonnage in 1980. Within that declining market, non-OECD countries - Republic of Korea, Brazil and Taiwan, and also some Eastern European countries, mainly Poland - have increased their share of production from 13.6 to 21.4 per cent, mainly at the expense of the EEC. Brazil and Republic of Korea are now the second and third largest producers of ships. These NICs' share of current capacity is probably larger than of current production and this is reflected in their share of orders by gross registered tonnage, up from 19 per cent in 1976 to a third in 1979. There have been attempts, within an OECD context, both to avoid ruinous export competition and also to manage cutbacks in capacity on an equitable basis. Nonetheless, there has been a spurt in direct subsidies for the construction of vessels amounting to, in some cases, around 30 per cent of the contract price and some tied aid programmes which have entailed ships being effectively 
given away to recipients. It must be said, however, in general that major traditional OECD shipbuilding countries have accepted policies implying very substantial and painful cutbacks in capacity in attempts to adjust to future lower levels of new shipbuilding; in German F.R. and Netherlands by 50 per cent between 1975 and 1980 and in the United Kingdom, Japan, Sweden and Italy by over 30 per cent. Also, although it is possible to quote extreme cases of subsidy protection there is, through the transparency of the mechanism, a degree of domestic budgetary restraint on protection which does not apply in the case of other non-tariff measures.

\section{Electronics}

43. By far the most important area of developing country engineering exports is electronics and, in particular, the assembly of finished consumer appliances and components. Both of these categories of goods contain many processes (though these are constantly changing) for which labour intensive assembly in developing countries is economically feasible. The average annual rate of growth of exports of electrical goods (in value terms at current prices) - even for the largest exporters, for example Singapore, Taiwan or Republic of Korea - has rarely fallen below 50 per cent per annum in the last fifteen years. ${ }^{1}$ In the period 1970 to 1978 the main NICs increased their exports to OECD countries from US $\$ 0.7$ billion (around 1 per cent of apparent consumption) to US $\$ 5$ billion (around 3.5 per cent of consumption). By contrast, Japanese exports to other OECD countries were just under US $\$ 9$ billion in 1978 , having grown even more rapidly.

44. This very rapid growth of imports might be expected to have created adjustment problems and demands for protection. There have been some but to a lesser extent than elsewhere for several reasons. The industries are rapidly growing and changing. New products

1. The main trends (up to the mid-1970s) are described in P. Plesch, Developing Countries' Exports of Electronics and Electrical Engineering Products, World Bank, 1978. There is some updating in V. Cable and J. Clarke, British Electronics and Competition with Newly Industrialising Countries, ODI, 1981 . 
emerge when those whose technology becomes mature or standardised for example, portable radios, black and white televisions and taperecorders - and gravitate to 'low wage' locations. There is little by way of community and craft tradition amongst the labour force to be found in the traditional labour intensive industries. Many manufacturers have, moreover, succeeded in making imports complementary to their own requirements, by using overseas subsidiaries to meet home market requirements for particular products (as with the Philips smallscreen television set plant in Singapore), by acting as importers for products made under subcontracting arrangements in the Far East but using their own brands and by producing specialised components in low wage economies. Not all firms have necessarily 'internationalised' their operations to the same degree, but enough to prevent a common protectionist front. Even where intra-firm transactions are not involved, manufacturers have had some control over the pace of technology transfer to potential competitors through patent licensing, for example, Phase Alternation Line (PAL) licenses have acted as the major restraint on firms in the NICs - other than European owned subsidiaries - acquiring the means to assemble colour televisions for sale in Europe. 1

45. Trade policy problems have however arisen and there are trade barriers of some importance on televisions. The USA negotiated OMAs on colour televisions with Republic of Korea and Taiwan in 1979 following an earlier agreement with Japan. The two events were closely linked. The quotas on Japanese televisions had led to imports from Taiwan doubling within a year and those from Republic of Korea increasing nine times. The quotas on Republic of Korea and Taiwan were renegotiated for two years in 1980 but a quota increase of 36 per cent was allowed. The rapid influx of televisions from new sources (including partially finished units from Mexico and Taiwan) has, however, ensured that there has been no increase in the US price and any costs to consumers have been marginal. ${ }^{2}$ The US also imposed, but has since reduced, additional tariffs on Citizen's Band radios.

1. The main papers are by E. Scibberas, Transfer of Technology in the Consumer Electronics Industry - The Television Sector OECD 1979 (unpublished) and Multinational Electronics Companies and National Electronics Policies JAI Press, 1977.

2. M.E. Mokre and D.G. Tarr, The Effects of Restrictions on United States Imports: Five Case Studies and Theory, Federal Trade Commission, 1980 . 
46. Protection of consumer electronics in Europe is somewhat uneven reflecting different national policies dating from pre-EEC days. European countries have now virtually ceased to produce battery radios, radio combinations and tape recorders, ceding the market to Asian NICs. The United Kingdom has also largely vacated the production of car radios and cassette combinations (although the two remaining producers are lobbying for protection). The United Kingdom and German F.R. - but not France and Italy, which maintain national quotas - have also accepted large import penetration of monochrome television sets. The United Kingdom has tried to arrest the process by imposing quotas selectively on imports from Republic of Korea and Taiwan. The action was particularly significant in that it was one of the very few uses of GATT's Article XIX, selectively, and, following a Republic of Korean submission to GATT, the quota was replaced by a VER. VERs have since been extended to new products ('music-centres') and other countries (Singapore and Thailand). The attempts currently being made to restructure the colour television industry - particularly in the United Kingdom are also predicated on the assumption that trade restrictions will be introduced on Far Eastern exporters once PAL licenses lose their effect.

47. There are currently moves - so far unsuccessful - to regulate imports at an EEC rather than a national level. Anti-dumping action, against Republic of Korean monochrome televisions is being pursued at a Community level. EEC countries have also sought to retain tariff protection - the 14 per cent nominal rate was left intact in the Tokyo Round - and televisions and radios are treated as 'sensitive' under the GSP. In Europe this sensitivity applies also to components. Transistors and television tubes are accorded tariff quotas and there are, in some member states, quantitative restrictions as wel1. The situation is in practice, however, extremely complex and, using special customs regimes, a large multinational company, like Philips, could arrange for components made in several 'low wage' countries to be assembled in Europe without payment of duty on the imported inputs.

48. The various actions - national and Community - reflect the growing insecurity of even the largest European companies in the 
face of Japanese, and (in some areas) NIC competition in both consumer products and components; insecurity which is partially shared in the USA. The picture, then, is a mixed one. In the field of televisions there are substantial barriers which are likely to grow as NICs start to export colour televisions. But this is unlikely to be an area in which developing countries find a strong or secure comparative advantage in any event since the process of manufacture of televisions is becoming highly automated, with a need for large-scale mass production and little labour content. Elsewhere, developing countries have found many product areas - components and consumer goods - where there are no barriers to speak of. Hong Kong, in particular, has expanded exports rapidly, encountering very little resistance, in less sensitive products than televisions: digital watches, calculators (though there is 'sensitive' tariff treatment for calculators in the EEC), many adaptations of basic portable radios, electronic games, and components. And in general, the involvement of large corporations gives developing countries powerful allies in keeping markets open.

\section{Semi-Manufactures: Chemicals, Metals, Paper and Board etc.}

49. We turn now to a group of industries very different in character from those which have gone before. The manufacturing process here is usually very capital intensive and the involvement of some developing countries, as competitors, is limited although some of them may have a comparative advantage stemming from specific circumstances: local, and relatively cheap raw materials; cheapenergy and petrochemical feedstock in oil producing states; the availability, at least in the richer OPEC countries, of capital to support major investments. The anxiety of established producers in developed countries about new sources of competition is due largely to the nature of the industries themselves: competition is usually on price rather than quality differences or brand, so new suppliers which are cost-competitive - after transportation - can break into unprotected markets relatively easily; semi-manufactures are more prone to business cycle variations than finished manufactures, and since the downturn in world economic activity in the mid-1970s there have been serious problems of excess capacity. But there is not strong evidence that developing countries are singled out for 
protectionist treatment. Trade friction has arisen in petrochemicals, steel, non-ferrous metals and paper between OECD countries themselves and developing countries - who are in any event minor suppliers - have, for the most part, been involved only incidentally.

50. Chemicals is a particularly sensitive area, especially petrochemicals. Major chemical companies have been a major influence on the textiles MFA, since 'downstream' clothing and fabric imports have been seen as a threat to 'upstream' man-made fibres, a sector which has suffered serious excess capacity problems. The sensitivity has also expressed itself in increasing attention to tariff questions. Most of the products recently given more extensive 'safeguard' treatment under the EEC's GSP scheme are chemicals and several important items - synthetic fibres, fertiliser, urea, dyestuffs - were exempted from full, or any, Tokyo Round cuts. Although the GSP measures suggest a growing awareness of competition from some NICs the real friction has been in the much larger trade between industrial countries, particularly concerning US exports of petrochemical products to Europe - leading to quota action.

51. Developing countries account only for around 3 per cent of all chemicals consumption - overall - in the industrialised world and growth of penetration is not especially rapid ( 5 per cent per annum in the $1970-79$ period). But there has been rapid growth, albeit at a very low absolute level, of imports of synthetic fibres, polymers and dyes. Bigger problems may arise in the late $1980 \mathrm{~s}$ with the emergence of petrochemical exporters in the Middle East, but some authoritative estimates suggest that, because of inevitable time lags, Saudi Arabia - the leading producer - is unlikely to have more than 2 per cent of effective world ethylene capacity by 1990 or the whole Middle East more than 4 per cent. ${ }^{1}$ More serious problems are threatening to arise from exports of petrochemicals by Taiwan and Republic of Korea to Japan but these developments do not appear to affect other countries.

1. J. Turner and L. Bedore, The Trade Politics of Middle East Industrialisation, Foreign Affairs, Winter 1978/79. (Recent news reports, however, suggest that progress is being made more rapidly than expected in these estimates). 
52. Several NICs, particularly Brazil and Republic of Korea (as well as Spain and Eastern European countries), are being affected by the crisis in the steel industries of the USA and the EEC; although mainly as a by-product of conflict between the EEC, the USA and Japan. Developing countries have contributed indirectly to the crisis of profitability and employment decline in establishec steel industries by building up their own self-sufficiency - from 40 per cent in 1974 to 60 per cent in 1980 - but their share of industrialised countries' markets remains very small, amounting to 1.5 per cent in 1979 , even if the countries of Southern Europe are included amongst the developing countries. Republic of Korea's Pohang complex ( 8.5 million ton capacity) probably contains the world's most efficient plant but projections suggest that Republic of Korea will remain a net importer into the 1990 s, exporting only some steel items. ${ }^{1}$

53. The USA has demanded VERs of Japan and the EEC since 1969.2 NICs only became involved with the introduction of the 'trigger' mechanism in 1977, which was re-introduced after a temporary suspension in 1980, for a five-year period. The mechanism provides in principle for an automatic triggering of anti-dumping action if prices fall below a price floor. After 1980, there has been an additional 'anti-surge' mechanism to ensure effective anti-dumping or anti-subsidy action once import penetration ceilings are breached or domestic excess capacity exceeded. Brazil - which encountered countervailing action on iron bars in the 1970 s - is currently at the centre of an enquiry, with other steel exporters, to establish the existence of export subsidies. Brazil accounts for 10 per cent of US imports and 2 per cent of the US market. If proven, the charge could lead to countervailing duties being imposed (and a bond is currently being exacted to cover estimated duties).

1. The main reports covering the role of ldcs in the world steel industry are by UNIDO, The World Iron and Steel Industry 1978 and by UNCTAD ( $I$. Walter), Trade and Structural Adjustment Aspects of the International Iron and Steel Industry: The Role of the Developing Countries, 1978. There is more recent data in OECD, The Steel Market in 1979 and Outlook for 1980, 1980 .

2. The background to protection is explained in I. Walter, Protection of Industries in Trouble - the Case of Iron and Stee 1 , World Economy, 1979. 
54. A11 EEC iron and steel trade is now regulated, inside and outside the Community, and production is also controlled. Brazil and Republic of Korea have been required to negotiate bilateral agreements, along with other countries which export to the EEC (although Republic of Korea keeps its exports well below the quota limit). There is also a minimum price system similar to that operating in the US. Despite the existence of import restricting measures and falling import penetration (from 18.1 per cent in 1978 to 13.0 per cent in 1980 in the USA, and from 12.0 to 11.5 per cent in the EEC) capacity utilisation has still fallen (from 86.6 to 71.0 per cent in the USA and from 65.6 to 64.6 per cent in the EEC). The pressure for import restrictions has grown and restrictions have been tightened in 1980 and 1981 .

55. Non-ferrous metals is one of the few areas in which market penetration by developing countries has actually fallen in the 1970s, mainly because of import substitution by some OECD countries which were previously major importers - Belgium, Sweden, Italy and the United Kingdom. Developing countries have, in any event, made negligible inroads into markets in the industrial countries for two of the main non-ferrous metals: aluminium and copper. This can, in part, be attributable to tariff escalation which has raised effective protection on aluminium and copper semis and products to somewhat more than the - rather low - nominal rates. But the reasons which determine the production location of non-ferrous metals are complex, and are related more to the technological characteristics of particular products, to transport costs and to the heavy involvement by transnational corporations, especially in aluminium, than to the structure or level of protection. 1

56. Paper is possibly an emerging problem because of the rapid growth - albeit from a very low base - of exports of pulpwood for paper processing, mainly from Brazil. Paper has traditionally been a highly sensitive item particularly in the EEC in its relations with the European Free Trade Association (EFTA) and the USA, and the proposed tariff change on one paper item (kraft liner paper)

1. The issues are clearly discussed in M. Radetski, Where should developing countries' minerals be prosessed? Wor 1 d Development, 1977. 
almost caused the Tokyo Round negotiated tariff package to become unstuck. Of more direct concern to developing countries have been other forms of wood processing especially plywood and veneer. Some industrial countries - the United Kingdom and Denmark in particular - welcome these imports, but others in the EEC have used the sensitive provisions of the GSP system to protect their industries (the nominal tariff is 13 per cent and there is tariff escalation). Australia has also sought to protect this industry. Countries affected are Malaysia, Philippines, Republic of Korea, Taiwan and Brazil. Another semi-manufacture which is of considerable interest to developing countries is leather. There has, however, been strong opposition amongst European tanners to the limitations placed by some of the developing countries on the release for export of unprocessed hides, and the consequential pressure on hide prices. Pressure has been mounting (so far ineffective) for an EEC ban on hides exports. There is also anxiety about direct developing country competition in tanned leather and (indirectly) in finished leather goods. But, tariffs are low and market penetration by developing countries is well above 20 per cent in most industrial countries, there being exceptionally low levels only for France and Japan. The Japanese leather industry, unlike most others, has traditionally enjoyed strict quota protection for social reasons.

\section{Other Manufactures}

57. There is, in addition to those mentioned above, a substantial number of smaller industry categories in which developing countries have become important suppliers. Many of these are light assembly operations drawing upon developing country comparative advantage in labour intensive manufacturing processes. Some of the most important items in this category are toys (where imports from developing countries to industrialised countries amounted to US $\$ 1,296$ million in 1979), a market penetration leve1, overall, in industrial countries of 13.6 per cent; sports goods (US \$459 million and 6.5 per cent); personal accoutrements like, umbrellas and pipes (US $\$ 484$ million and 7.5 per cent); musical instruments (US $\$ 142$ million and 3.8 per cent); and some items which were touched upon under engineering but possibly have more in common with those here, for example, watch-making (US $\$ 990$ million and 13.9 per cent) and 
photographic equipment (US $\$ 472$ million and 2.5 per cent). Common to all of these categories is exceptional growth of market penetration and relative freedom from trade restrictions. While toys and sports goods, for example, have to confront tariffs greater than the average, they were not exempted from the full Tokyo Round cuts and in the main consuming markets, the EEC, they do not suffer 'sensitive' GSP status. One explanation could be that manufacturers have been able to devise adjustment mechanisms which have given them an involvement - through direct investment and importing - in developing country exports. These are also relatively insignificant industries unlikely to be able to mount a substantial lobbying campaign. And the extreme cheapness of some items has created, in some instances, a mass market for what was formerly a speciality. There are, of course, exceptions: France has created quota barriers against some Far Eastern imports of umbrellas and toys.

58. In the future, developing countries will enjoy a much wider spread of exports and there is evidence of rapid increases in some products - glass and pottery, ceramics, furniture and other wood products, printing and plastic articles. 1 In several cases antidumping or other action has been taken (for example, on ceramics and furniture) but the scale of restrictions, like the trade itself, is, as yet, sma11.

\section{Conclusions}

i. The concept of "protectionism" in manufacturing trade is an elusive one since many trade restrictions are informally agreed or secret. Some trade which is nominally 'free' is, in fact, regulated through intra-firm transactions or patents, albeit privately administered. Hence, measurement is difficult and interpretation sometimes ambiguous. Attention is inevitably directed to the most visible impediments to market access, particularly tariffs. In most product categories tariffs have been superseded in importance by quotas, VERs or less visible NTBS, though they remain significant for many items even after allowance for tariff preferences.

1. There is a detailed review of industry prospects in A. Edwards The Newly Industrialised Countries and their Impact on Western Manufacturing EIU Special Report No.73, 1979 . 
ii. To the extent that it is possible to quantify changes, there is evidence of an upsurge of protectionist measures in the period 1974-78. International agencies are now very concerned that the climate of trade policy has deteriorated again. Developing countries appear to have been differentially affected by new protectionist measures. The level of tariff and NTBs which they face in industrial countries is also significantly higher than that faced by industrial courtries. The agreement of GATT codes, in principle to cover NTBS, offers some possibility of relief but so far precise definitions, easily enforceable, have not emerged.

iii. The growth of developing country exports to industrial countries, and market penetration by them, was very rapid in the 1970 s, although the levels attained remain very modest for most products and overal1. There was a distinct slowing down in market penetration by developing countries in the late 1970 s to which protectionism has contributed, together with a generally less favourable environment for trade in the context of recession.

iv. The main problem concerns textiles, and clothing. This is such a significant area of manufacturing trade for developing countries, and increasingly so for the poorer and smaller countries, that they regard developments under the MFA as a barometer of industrial country protectionist attitudes in general. Their experience with the MFA since 1977 in particular has been discouraging. The single most important measure which could now be taken by industrial countries in manufactures is to set in train a trade liberalisation process in this sector. The worst step would be a tightening of restrictions, as the EEC, in particular, now threatens to do.

v. There have been some worrying signs of strong protectionist pressure in other sectors - shoes, consumer electronics, metals - although these concern trade among industrial countries primarily (steel and consumer electronics) or else have not led to severe controls(shoes). Part of the anxiety felt by developing country exporters is a result of fears that the textiles MFA could serve as a precedert for other sectors; though, so far, these fears 
have not been realised to any great extent. There are, in addition many manufacturing product areas, notably in engineering broadly defined, in which spontaneous market adjustment has taken place to an encouraging degree, permitting developing countries to develop their comparative advantage in some branches of manufacturing trade. 